S. J. Bauer, M. Friedman, and J. Handin

$\mathrm{DOE} / \mathrm{ER} / 10361--\mathrm{T} 2$

\title{
DE83 015143
}

EFFECTS OF WATER-SATURATION ON STRENGTH AND DUCTILITY OF THREE IGNEOUS ROCKS AT EFFECTIVE PRESSURES TO 50 MPA AND TEMPERATURES TO PARTIAL MELTING

S. J. Bauer, M. Friedman, and J. Handin

Center for Tectonophysics

Texas A\&M University

College Station, TX 77843

\section{INTRODUCTION}

Energy extraction from the geothermal regime in and above buried magma-chambers requires that rocks be drillable (brittle or semi-brittle) and boreholes be stable to depths of $10 \mathrm{~km}$, at temperatures to partial melting, and in a natural or manmade aqueous environment. Critical are the short-term strengths and ductilities that would govern during and immediately after drilling, and the longer-term, timedependent response, that would influence the stabil$i$ ty of a borehole over the multi-year life-expectancy of a geothermal well.

At least initially, we chose to investigate the short-term failure strengths and strains at failure of room-dry and water-saturated, cylindrical specimens ( 2 by $4 \mathrm{~cm}$ ) of Charcoal Granodiorite (CG), Mt. Hood Andesite (MHA), and Cuerbio Basalt (CB) at a strain rate of $10^{-4} \mathrm{~s}^{-1}$, at effective confining pressures of 0,50 , and $100 \mathrm{MPa}$ and at temperatures to partial melting. Previous laboratory work needed to be augmented because virtually all testing above $500^{\circ} \mathrm{C}$ had been done at either atmospheric pressure (e.g., Murrell and Chakravarty, 1973), at too high a confining pressure (e.g., Handin, 1966; Carter, 1976; Tull is and Yund, 1977; Carter and Kirby, 1978; Tullis, 1979), or at uncertain effective pressures (e.g., Murreli and Ismai 1, 1976; Tullis and Yund, 1978; Van der Molen and Paterson, 1979). Available data on creep of crystalline rock have suggested that deformation rates are very slow even at elevated temperatures and pressures (Carter and Kirby, 1978; Handin and Carter, 1980; and Carter et a $7 ., 1981$ ). Only when partial melting occurs do rock-strengths vanish and relatively low viscosities obtain (Van der Molen and Paterson, 1979; Friedman et al., 1980). Hence our emphasis is on the short-term effects. Previously we dealt with room-dry specimens of these three rocks and with the Newberry Rhyolite Obsidian (Friedman et al., 1979, 1980). This was necessary because "dry-out" zones may exist immediately above buried magma and a data-base for dry rocks is needed for comparison with water-saturated counterparts in order to distinguish between effective pressure and water-weakening effects. Herein we report on experiments on the water-saturated specimens.

\section{APPARATUS AND PROCEDURES}

The triaxial-compression apparatus, including the hydraulic press and internally-heated pressure cell, the starting materials, sample preparation, and plotting of true axial differential stress (MPa) against conventional strain (percent shortening) are fully described in previous publications (Friedman et al., 1979, 1980). The accuracy of measurements of differential force, shortening, external confining pressure $\left(P_{c}\right)$, and internal pore pressure $\left(P_{p}\right)$ is of the order of \pm 2 percent. Temperature $(T)$ is known within $\pm 5^{\circ} \mathrm{C}$, and the maximum gradient along the length of the specimen is $30^{\circ} \mathrm{C}$ at $1000^{\circ} \mathrm{C}$ nominal. In brief, (1) the 2 by $4-\mathrm{cm}$ cylindrical specimens are vacuum-saturated with tap water and stored under water until they are jacketed in thin-walled, annealed copper tubes and emplaced within the internal furnace of the test cell; (2) a small axial force is applied to seat and seal off the specimen and the cell is purged of air and filled with the confining medium of argon; (3) the axial force, external confining pressure, and internal pore pressure are raised simultaneously to the desired effective confining pressure, $\mathrm{P}_{\mathrm{e}}=\mathrm{P}_{\mathrm{C}^{-}} \mathrm{P}_{\mathrm{p}} ;$ (4) the specimen is heated to test temperature at about $10^{\circ} \mathrm{C} / \mathrm{min}$; (5) the specimen is soaked for 15 min, effective confining pressure and temperature being readjusted if necessary (increasing soak-time to 1 hour does not significantly affect the results); (6) the specimen is loaded axially such that $\sigma_{1}>\sigma_{2}=\sigma_{3}=P_{e}$, where $\sigma_{i}$ are the effective principal compressive stresses, $\mathrm{P}_{\mathrm{e}}$ remaining sensibly constant because strains before macroscopic fracture are small, only about 1 percent.

Using the laboratory data to predict borehole stability where $\sigma_{1}>\sigma_{2}>\sigma_{3}$, we shall assume that ultimate compressive strength at failure, the peak value of the differential stress, $\sigma_{1}-\sigma_{3}$, at a particular temperature, is a function only of mean stress, $\sigma_{m}=\left(\sigma_{1}+\sigma_{2}+\sigma_{3}\right) / 3$. Thus for each test we compute $\left(\sigma_{1}-\sigma_{3}\right)$ and $\sigma_{m}$ and list them together with the total shortening at macroscopic failure that serves as a measure of relative ductility (Table 1). We aiso show the angle $\theta$ between the load axis $\left(\sigma_{1}\right)$ and the macroscopic fautt.

\section{EXPERIMENTAL RESULTS}

The experimental data on Charcoal granodiorite, Cuerbio basalt, and Mt. Hood andesite are listed in Table 1. All tests were done at a nominal strainrate of $10^{-4} / \mathrm{s}$, and all were stopped short of total loss of cohesion of the deformed specimens. Stressshortening curves are similar to those published previously (Friedman et a1., 1979, 1980). Those for the CG show well defined uitimate strengths at $<2 \%$ shortening and then pronounced work-softening as sl ip occurs along faults. Those for the MHA exhibit ultimate strengths at $\leq 3 \%$ shortening, and quasisteady-state, ductile flow, particularly at the higher temperatures where partial melting occurs. The plots of ultimate strength versus temperature for the water-saturated rocks are compared with their counterparts for dry specimens (Figures 1, 2, 3).

\section{Charcoal Granodiorite}

At zero effective confining pressure $\left(P_{C}=P_{p}=0\right.$ or $P_{C}=P_{p}=50 \mathrm{MPa}$ ) strength decreases gradually with increasing temperature until it vanishes at 


\section{DISCLAIMER}

This report was prepared as an account of work sponsored by an agency of the United States Government. Neither the United States Government nor any agency Thereof, nor any of their employees, makes any warranty, express or implied, or assumes any legal liability or responsibility for the accuracy, completeness, or usefulness of any information, apparatus, product, or process disclosed, or represents that its use would not infringe privately owned rights. Reference herein to any specific commercial product, process, or service by trade name, trademark, manufacturer, or otherwise does not necessarily constitute or imply its endorsement, recommendation, or favoring by the United States Government or any agency thereof. The views and opinions of authors expressed herein do not necessarily state or reflect those of the United States Government or any agency thereof. 


\section{DISCLAIMER}

Portions of this document may be illegible in electronic image products. Images are produced from the best available original document. 
about $1050^{\circ} \mathrm{C}$ where partial melting is pervasive (Figure 1). The reproducibility of duplicate tests under the same conditions is regarded as relatively good for triaxial testing of statistically homogeneous and isotropic rocks like the granodiorite. The strengths of dry and water-saturated specimens are virtually identical at $400^{\circ}$ and $1015^{\circ} \mathrm{C}$; wet specimens are somewhat the stronger in the range of $460^{\circ}$ to $990^{\circ} \mathrm{C}$.

At 50-MPa effective pressure $\left\langle P_{c}=50, P_{p}=0\right.$ or $\left.P_{c}=100, P_{p}=50\right)$ the rock is much stronger at all temperatures. Reproducibility is generaliy only fair, but the strengths of wet specimens at $800^{\circ}$ and $810^{\circ} \mathrm{C}$ are virtually identical, and the strengths of all wet specimens in the range of $615^{\circ}$ to $900^{\circ} \mathrm{C}$ lie close to those of dry specimens at $\mathrm{Pe}_{\mathrm{e}}=50$ and far below those at $P_{c}=P_{e}=100 \mathrm{MPa}$, suggesting that pore pressures must be nearly fully effective.

The presence of water does not significantly affect either strength or ductility. All specimens are essentially brittle, failing by macroscopic shear fracturing at strains of the order of 1 percent (Table 1).

\section{Mt. Hood Andesite}

This rock is finer-grained but more porous and permeable that the $C G$, and its matrix contains minor amounts of glass. It is much weaker than the granodiorite at all effective pressures and temperatures. At $P_{c}=p_{p}=0$, the strength of the dry andesite remains nearly constant as temperature is increased from $25^{\circ}$ to $1000^{\circ} \mathrm{C}$, but suddenly vanishes at about $1050^{\circ} \mathrm{C}$ (Figure 2). Reproducibility of tests is regarded as good. The strengths of dry and of wet specimens at $P_{c}=P_{p}=50 \mathrm{MPa}$ are identical at $615^{\circ} \mathrm{C}$, but the wet andesite is much the weaker at $700^{\circ} \mathrm{C}$, and its strength vanishes when partial melting occurs, unl ike that of the granodiorite. The melting temperature for this rock is reduced $>150^{\circ} \mathrm{C}$ by the presence of water.

At the higher $50-\mathrm{MPa}$ effective confining pressure $\left(P_{c}=50, P_{p}=0\right.$ or $\left.P_{c}=100, P_{p}=50\right)$ this rock is much stronger at all temperatures. Again contrary to the behavior of the granodiorite, the strength of wet andesite in the range of $600^{\circ}$ to $920^{\circ} \mathrm{C}$ lies we 11 below that of the dry rock and far below that at $P_{c}=100, P_{p}=0$. Furthermore, the strains at failure of the wet specimens are somewhat the larger.

\section{Cuerbio Basalt}

Relatively few data are available for this dense, tight rock, but the effects of water saturation are still evident (Figure 3 ). The strengths of the dry rock at $P_{C}=0$ is little affected by heating from $25^{\circ}$ to $900^{\circ} \mathrm{C}$. At $\mathrm{P}_{\mathrm{C}}=50$, the strength drops from about $500 \mathrm{MPa}$ at $25^{\circ} \mathrm{C}$ to about 350 at $600^{\circ}$ to about 100 at $1000^{\circ} \mathrm{C}$. At $P_{C}=100$, it drops from 465 at $700^{\circ}$ to 180 at $1000^{\circ}$.

The strength of the water-saturated basalt at zero effective confining pressure $\left(P_{c}=P_{p}=50 \mathrm{MPa}\right)$ is much like that of the dry rock to about $750^{\circ} \mathrm{C}$; above $800^{\circ}$ it drops rapidiy to $60 \mathrm{MPa}$ at $945^{\circ}$. The basa?t too is essentially brittle at all pressures and temperature (Table ?).

\section{Mechanism of Deformation}

As noted in Table 1 most of the water-saturated rock specimens are macroscopically shattered, i.e., they failed along two or more shear fractures or faults. This often gives rise to an apparent steadystate or work-softening stress-shortening curve. Crystal plastic flow is conspicuous only in favorably oriented, kinked biotite. True ductile flow occurs with incipient meiting. In its very incipient stages this melting occurs at grain boundaries associated with biotite or hornblende, with in feldspar and quartz grains as manifest by isolated patches of vesicules, or aiong fractures similar to that found by Van der Molen and Paterson (1979).

Aside from the incipient melting, microfracturing and the coalescence of microcracks into the macroscopic faults are the major mechanisms of deformation. Quantitative assessment of the abundance of these microfractures in wet tests shows that they are not more abundant than in dry counterparts. That is, about the same number of microfractures occurs prior to failure, wet or dry.

\section{MECHANISMS FOR WATER-WEAKENING}

Water-weakening can owe to (a) chemisorption or stress corrosion effects at crack tips that reduce fracture strengths (e.g., review by Anderson and Grew, 1977), (b) lowered melting points, and (c) lowering of the critical resolved shear stresses for dislocation gliding, i.e., yield strengths for crystal-plastic mechanisms (e.g., Griggs and Blacic, 1965; Griggs, 1974; Balderman, 1974; Tull is, 1979). A11 three effects involve hydration of the silanol bonds in silicates. The higher is the temperature, the more significant is this phenomenon likely to be (Griggs, 1967). Without detailed thin-section and perhaps TEM studies (scheduled for the future), we can not say which of these mechanisms has lowered the strength of the andesite at elevated temperatures, but it is generally recognized that $\mathrm{H}_{2} \mathrm{O}$ must gain access to the crystal surfaces (item a, above) and then to their substructures ( $i$ tems $b$ and $c$, above) to effect the hydrolytic weakening. It is not surprising therefore, that of the three rocks tested, the andesite shows the greatest weakening probably because its relatively larger porosity (1012 percent) allows greater access of the pore water to its internal surfaces.

In the ductile regime temperature $\left(300-500^{\circ} \mathrm{C}\right)$ affects the water-weakening of quartz (Griggs, 1967; Balderman, 1974). Our maximum temperatures much exceed these. More recently however, a pressure effect has been found, as water is driven from the surfaces of pores and cracks into the adjacent crystal structures at high pressure (Tutlis, 1979). Our pore pressures ( 50 and $100 \mathrm{MPa}$ ) are small compared to those ( 1000 and $1500 \mathrm{MPa}$ ) needed in the laboratory to achieve this effect (Tullis and Yund, 1978), so that water-weakening ( $i$ tem $c$, above) is not expected. Instead, the brittle response of our specimens suggests that the water-weakening of the andesite is due to stress-corrosion and/or the reduced melting temperature. This view is supported by the microfracture-abundance data which indicate that the same number of microfractures form regardless of water-content. This number appears to be critical for failure, and when the specimen is waterweakened this critical assemblage of fractures is 
obtained at a lower externally imposed differential stress. Thus, local fracture strengths must be reduced in the presence of water.

\section{PARTIAL MELTING}

In our water-saturated tests only incipient stages of partial melting have been obtained with $<3$ percent glass found along grain boundaries and axial fractures in CG specimen 308 and MHA specimens 297, 305, 312 , and 325 (Table 1 ). Our results differ from those of Van der Molen and Paterson (1979) on a fine-grained quartz monzonite in two important ways. They observe (1) more partial melting than we do at $800^{\circ} \mathrm{C}$; and (2) a gradual decrease in strength from about $250 \mathrm{MPa}$ at 5 percent melt to about $60 \mathrm{MPa}$ at 15 percent melt, and then a drop to $<1 \mathrm{MPa}$ at 24 percent melt. In contrast we find larger strength reductions from much smaller amounts of melt. The first result probabiy obtains because their specimens are "soaked" at $P$ and $T$ for 100 minutes prior to shortening (as opposed to 15 minutes for ours) and their strain-rate $\left(10^{-5} s^{-1}\right)$ is one order of magnitude slower than ours. We have no ready explanation for the second result because their effective pressures are unknown.

\section{BOREHOLE STABILITY}

The rationale for our simplistic scheme to predict borehole stability is detailed by Friedman et a1. $(1979,1980)$. In brief, (1) the experimenta? ultimate differential stress and mean stress at failure for each rock are plotted in three (Figure 4) or two dimensions (Figure 5). (2) Purely mechanical borehole-stresses are calculated from elastic theory with certain assumptions about the far-field stresses ( $\sigma_{h}$ equal in all directions and $\sigma_{h} / \sigma_{v}=2,1$, or 0.5 ), borehole filling (open or filled with a material with the density of $1.0 \mathrm{~g} / \mathrm{cc}$ ) and the water content of the rock (dry or saturated) (Friedman et a1.., 1979,

Table 6). (3) The borehole stresses as a function of depth are then drawn as surfaces in three dimensions or straight lines (loci) on the plots containing the failure data (Figures 6 and 7 , respectively). (4) In order to use the laboratory data to predict failure of a borehole, we assume that ultimate strength $\left(\sigma_{1}-\sigma_{3}\right)$ at failure is a function only of the effective mean stress, $\sigma_{m}=\left(\sigma_{1}+\sigma_{2}+\sigma_{3}\right) / 3$ and temperature. (5) If at a given mean pressure, say $50 \mathrm{MPa}$, the strengths for a given rock exceed the borehole differential stress, then the borehole will be stable. That is, it will not fail by shear fracturing in the short term. (6) Intersections of lines connecting strength data for a given temperature and the borehoie-stress loci mark the boundaries between the fields of stability, containing all points to the left of the loci of borehole stresses, and of instability, containing all points to the right. Stated another way, the borehole will fail if the borehole-stress-loci intersect the failure surface (Figure 4). Predictions based on the dry strengths of all three rocks are given in Friedman et al. (1979, 1980).

Here we concentrate on the likelihood of stable boreholes in water-saturated CG and MHA (Figures 7 and 8 , respectively). The available data indicate (1) both rocks would afford stable boreholes to $>10$ $\mathrm{km}$ if $\sigma_{h} / \sigma_{y}$ were 1.0 and the boreholes were filled with a material of density $1.0 \mathrm{~g} / \mathrm{cc}$; (2) boreholes in CG would be stable to $>10 \mathrm{~km}$ at all assumed conditions provided that the temperature did not exceed about $800^{\circ} \mathrm{C}$; (3) boreholes would be much less stable in the water-weakened MHA, and depending upon the far-field conditions would fail at $700^{\circ} \mathrm{C}$ at depths ranging from 2 to $5 \mathrm{~km}$; and (4) boreholes even in the MHA would be stabilized appreciably if kept cool $\leq 700^{\circ} \mathrm{C}$.

We have addressed the matter of short-term borehole stability. They do not consider time effects, irregularities at the borehole wall that would concentrate the stresses and enhance failure, or existing natural fractures. Nor have we treated superposed thermomechanical stresses arising from cooling a borehole in hot country rock. These would tend to diminish the differential stresses at the borehole wall and so promote stability.

\section{CONCLUSIONS}

Data from water-saturated specimens of the granodiorite and andesite, compared to room-dry counterparts, indicate (1) the pore pressures are essentially communicated throughout each test specimen so that they are fully effective; (2) at $\mathrm{Pe}_{\mathrm{e}}=0$ and $50 \mathrm{MPa}$ $\left[P_{c}\right.$ and $P_{p}$ of $50 \mathrm{MPa}$ and of 100 and $50 \mathrm{MPa}$, respectively] the granodiorite does not water-weaken; (3) at these same effective pressures the more porous and finer-grained andesite begins to exhibit waterweakening at about $600^{\circ} \mathrm{C} ;(4)$ at $\mathrm{P}_{e}=0$ and $870-900^{\circ} \mathrm{C}$ the andesite's strength averages $20 \mathrm{MPa}$ while the strength of dry specimens at the same $P$ and $T$ exhibit a strength of $100 \mathrm{MPa}$, i.e., strength is reduced by a factor of $5 ;(5)$ at $\mathrm{Pe}_{e}=50 \mathrm{MPa}$ and $920^{\circ} \mathrm{C}$ the andesite's wet strength is $45 \mathrm{MPa}$ compared to 160 $\mathrm{MPa}$ dry; (6) the basalt at $\mathrm{P}_{\mathrm{e}}=0$, appears to be water-weakened at $800^{\circ} \mathrm{C} ;(7)^{2}$ ductility of the watersaturated specimens deformed at temperatures less than that of melting exhibit ultimate strengths at less than 2 percent shortening and then work-soften along faults, i.e., like their dry counterparts the rocks remain brittle up to the onset of melting; (8) again as do the dry counterparts, the wet specimens deform primarily by microscopic fracturing that coalesces into one or more macroscopic faults; and (9) the temperature for incipient melting of the andesite is decreased $>150^{\circ} \mathrm{C}$ in the watersaturated tests.

Extrapolations of strength and ductility data for both wet and dry specimens indicate: (1) crystalline rocks should be drillable because they remain brittle until partial melting occurs, and penetration rates should increase with temperature because of a corresponding decrease in brittle fracture strength; (2) boreholes in "water-filled" holes should be stable to $>10 \mathrm{~km}$ at temperatures $<\mathrm{Tm}$; (3) if temperatures are kept to $\leq 700^{\circ} \mathrm{C}$, even open boreholes in granodiorite are apt to be stable to $>10 \mathrm{~km}$; and (4) open boreholes in the andesite would be much less stable, and at similar temperatures would fail at 2 to $5-\mathrm{km}$ depth. Work to date on intact specimens suggests it is scientifically feasible to drill to buried magma chambers at depths to $10 \mathrm{~km}$. Boreholes can be stabilized by keeping them as cool as possible and subject to a borehole pressure equivalent to that of a column of water at $25^{\circ} \mathrm{C}$.

\section{ACKNOWLEDGMENTS}

This work was supported by the Office of Basic Energy Sciences, Department of Energy, Contract No. DE-AS05-79-ER10361. 


\section{REFERENCES}

Anderson, 0. L., and P. C. Grew, 1977, Stress corrosion theory of crack propagation with applications to geophysics, Review of Geophysics and Space Physics, Vol. 15, pp. 77-104.

Balderman, M. A., 1974, The effect of strain rate and temperature on the yield point of hydrolytically weakened synthetic quartz, Journal of Geophysical. Research, Vol. 79, pp. 1647-1652.

Carter, N. L., 1976, Steady state flow of rocks, Review of Geophysics and Space Physics, Vol. 14, pp. 30T-35\%.

Carter, N. L., and S. H. Kirby, 1978, Transient creep and semibrittle behavior of crystalline rocks, Pure and Applied Geophysics, Vol . 116, pp. 806839 .

Carter, N. L., D. A. Anderson, F. D. Hansen, and R. L. Kranz, 1981, Creep and creep-rupture of granitic rocks, in The Handin Volume, American Geophysical Union, Geophysical Monograph Series, in press.

Friedman, M. , J. Handin, N. G. Higgs, and J. R. Lantz, 1979, Strength and ductility of four dry igneous rocks at low pressures and temperatures to partial melting, proceedings of the 20th U.S. Symposium on Rock Mechanics, Austin, pp. 35-50.

Friedman, M., J. Handin, N. G. Higgs, J. R. Lantz, and S. J. Bauer, 1980, Strength and ductility of room-dry and water-saturated igneous rocks at low pressures and temperatures to partial melting, Sandia Laboratories, Final Report Contract No. 3-2242, $86 \mathrm{p}$.

Griggs, 0., 1967, Hydrolytic weakening of quartz an other silicates: Geophysical Journal of the Royal Astronomical Society, Vol. 14, pp. 19-31.

Griggs, D., 1974, A model of hydrolytic weakening in quartz: Journal of Geophysical Research, Vol. 79, pp. 1653- 667 .

Griggs, D. and J. D. Blacic, 1965, Quartz: Anomalous weakness of synthetic crystals: Science, Vol. 147, pp. 292-295.

Handin, J., 1966, Strength and ductility, Section 11 , in Handbook of Physical Constants, Revised Edition, Geological Society of America Memoir 97.

Handin, J., and N. L. Carter, 1980, Rheological properties of rocks at high temperatures, in Proceedings of the 4th Congress International Society of Rock Mechanics, Vol. 3, Montreux, Switzerland, pp. 97-106.

Murre11, S. A. F., and S. Chakravarty, 1973, Some new rheological experiments on igneous rocks at temperatures up to $1120^{\circ} \mathrm{C}$, Geophysical Journal of the Royal Astronomical Society, Vol. 34, pp. 217250 .

Murrel1, S. A. F., and I. A. H. Ismail, 1976, The effect of temperature on the strength at high confining pressure of granodiorite containing free and chemically-bound water, Contributions Mineralogy Petrology, Vol. 55, pp. 317-330.

TulTis, J.A., 1979, High temperature deformation of rocks and minerals, Reviews of Geophysics and Space Physics, Vol. 17, pp. 1137-1154.

TulTis, J., and R. A. Yund, 1977, Experimental deformation of dry Westerly granite, Journal of Geophysical Research, Vo1. 82, pp. 5705-57/8.

Tullis, J. A. and R. A. Yund, 1978, Water-weakening of experimentally deformed Westerly Granite: Journal of Geophysical Research, Vol, 82 pp. 5705-5718.

Van der Moien, I., and M. S. Paterson, 1979, Experimental deformation of partially-melted granite,
Contributions Mineralogy Petrology, Vol. 70, pp. 299-318.

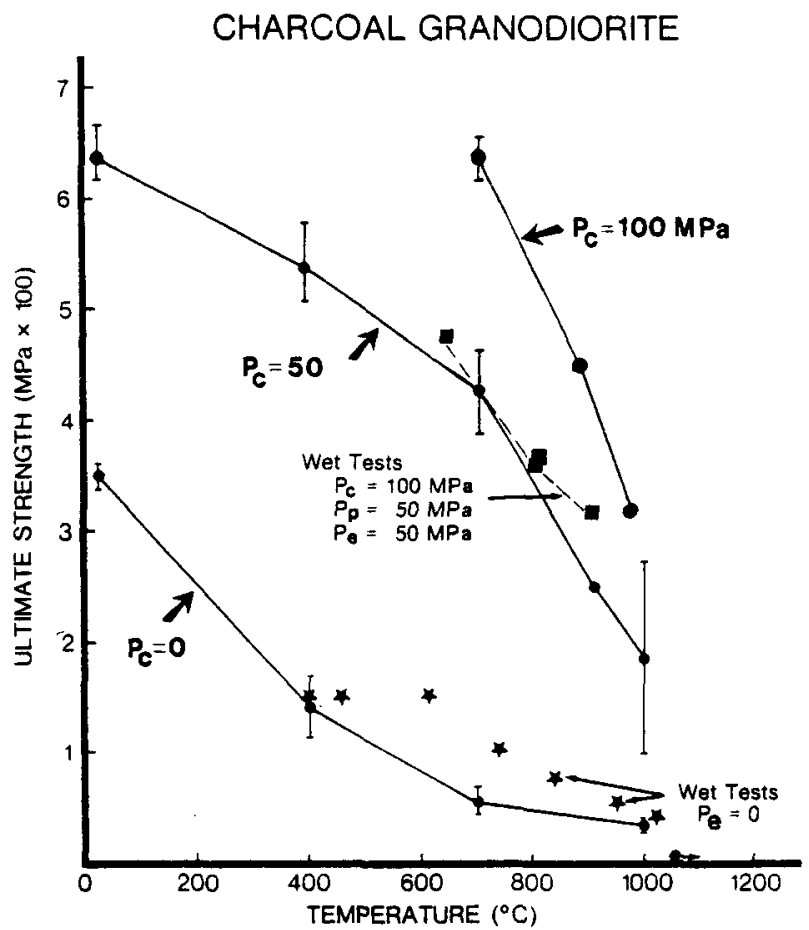

Figure 1. Ultimate strength versus temperature for Charcoal Granodiorite. Solid circles show data points at confining pressures of 0,50 , and $100 \mathrm{MPa}$ for room-dry specimens. Solid stars and squares show data points for water-saturated specimens at $\mathrm{Pe}_{\mathrm{e}}$ of 0 and $50 \mathrm{MPa}$, respectively.

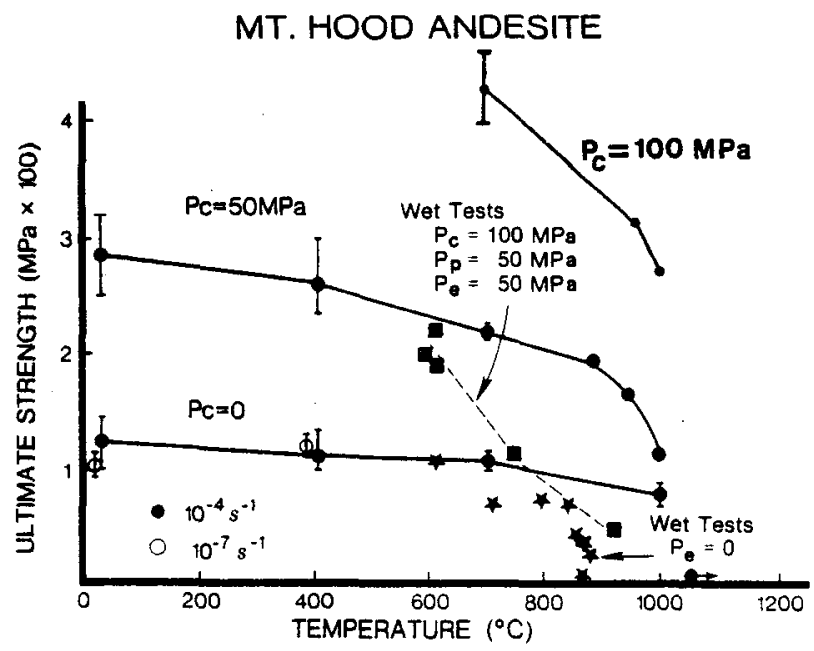

Figure 2. Ultimate strength versus temperature for Mt. Hood Andesite. Solid circles show data for roomdry specimens at confining pressures of 0,50 , and $100 \mathrm{MPa}$. Stars and squares show data for water-saturated specimens at $\mathrm{P}_{e}$ of 0 and $50 \mathrm{MPa}$, respectively. 
Tabie 1. Experimental Data for Water-Saturated Charcoal Granodiorite, Cuerbio Basalt and Mt. Hood Andesite Shortened at $10^{-4} \mathrm{~s}^{-1}$.

\begin{tabular}{|c|c|c|c|c|c|c|c|}
\hline $\begin{array}{l}\text { Rock Type } \\
\text { and } \\
\text { Specimen No. }\end{array}$ & $\begin{array}{l}\text { Confining } \\
\text { Pressure } \\
\text { (MPa) }\end{array}$ & $\begin{array}{l}\text { Pore } \\
\text { Pressure } \\
\text { (MPa) }\end{array}$ & $\begin{array}{l}\text { Effective } \\
\text { Pressure } \\
\text { (MPa) }\end{array}$ & $\begin{array}{l}\text { Temp. } \\
\left({ }^{\circ} \mathrm{C}\right)\end{array}$ & $\begin{array}{l}\text { Mean } \\
\text { Stress } \\
\text { (thPa) }\end{array}$ & $\begin{array}{l}\text { Ultimate } \\
\text { Strength } \\
(\mathrm{MPa})\end{array}$ & $\begin{array}{l}\text { Shorte } \\
\text { at } F a i \\
(\%) \\
(\%)\end{array}$ \\
\hline \multicolumn{8}{|c|}{ CHARCOAL GRANODIORITE } \\
\hline 280 & 100 & 100 & 0 & 400 & 50 & 150 & 0.7 \\
\hline 286 & 50 & 45 & 5 & 460 & 50 & 150 & - \\
\hline 287 & 50 & 45 & 5 & 610 & 50 & 150 & - \\
\hline 289 & 50 & 50 & 0 & 740 & 35 & 100 & 1.0 \\
\hline 291 & 50 & 50 & 0 & 835 & 25 & 75 & 1.0 \\
\hline 294 & 50 & 50 & 0 & 945 & 20 & 55 & 0.9 \\
\hline 308 & 50 & 50 & 0 & 1015 & 15 & 40 & 0.6 \\
\hline 311 & 50 & 50 & 0 & 990 & 15 & 40 & 0.4 \\
\hline 320 & 100 & 50 & 50 & 615 & 210 & 485 & 1.3 \\
\hline 314 & 100 & 50 & 50 & 800 & 170 & 360 & 1.7 \\
\hline 317 & 100 & 50 & 50 & 900 & 155 & : 315 & 1.6 \\
\hline 324 & 100 & 50 & 50 & 810 & 174 & 372 & 1.5 \\
\hline \multicolumn{8}{|c|}{ CUERB IO BASALT } \\
\hline 296 & 50 & 50 & 0 & 415 & 85 & 255 & 0.6 \\
\hline 304 & 50 & 50 & 0 & 765 & 80 & 235 & 0.8 \\
\hline 307 & 50 & 50 & 0 & 916 & 30 & 90 & 0.9 \\
\hline 309 & 50 & 50 & 0 & 350 & 45 & 135 & 0.3 \\
\hline 310 & 50 & 50 & 0 & 945 & 20 & 60 & 0.1 \\
\hline 318 & 100 & 50 & 50 & 820 & 110 & 180 & 1.0 \\
\hline \multicolumn{8}{|c|}{ MT. HOOD ANDESITE } \\
\hline 306 & 50 & 50 & 0 & 615 & 35 & 105 & 0.6 \\
\hline 290 & 50 & 50 & 0 & 720 & 25 & 70 & 0.6 \\
\hline 300 & 50 & 50 & 0 & 800 & 25 & 70 & 0.6 \\
\hline 301 & 50 & 50 & 0 & 845 & 20 & 55 & 0.8 \\
\hline 302 & 50 & 50 & 0 & 855 & 15 & 40 & 0.8 \\
\hline 303 & 50 & 50 & 0 & 370 & 10 & .35 & 0.8 \\
\hline 297 & 50 & 50 & 0 & 870 & 0 & 5 & 1.0 \\
\hline 305 & 50 & 50 & 0 & 880 & 10 & 25 & 0.7 \\
\hline 327 & 100 & 50 & 50 & 600 & 120 & 205 & 1.5 \\
\hline 319 & 100 & 50 & 50 & 610 & 125 & 225 & 2.0 \\
\hline 324 & 100 & 50 & 50 & 610 & 115 & 190 & 3.2 \\
\hline 312 & 100 & 50 & 50 & 745 & 85 & 110 & 3.4 \\
\hline 325 & 100 & 50 & 50 & 920 & 65 & 45 & 3.1 \\
\hline
\end{tabular}

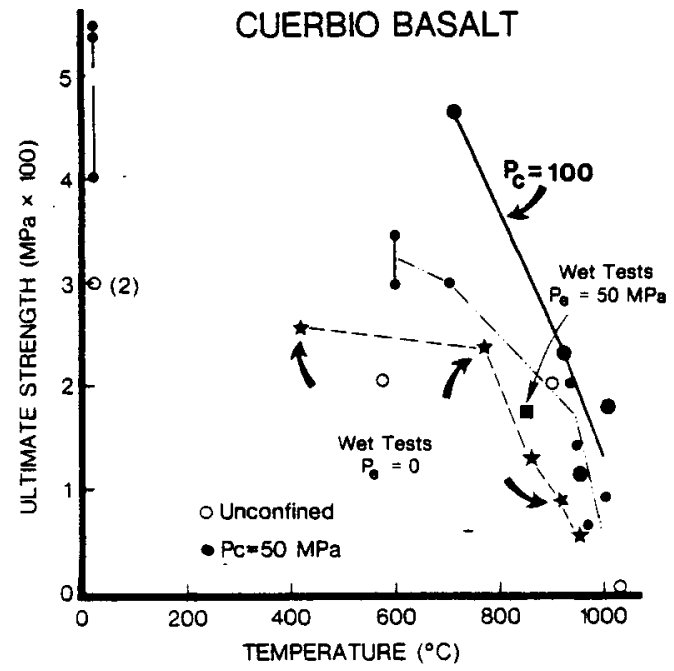

Figure 3. Uitimate strength versus temperature for Cuerbio Basalt. Solid and open circles show data for room-dry specimens at confining pressures of 0 , 50 , and $100 \mathrm{MPa}$. Solid stars and squares show data for water-saturated specimens at $P_{e}=0$ and $50 \mathrm{MPa}$, respectively.
Shattered, work-5oftened to $50 \mathrm{MPa}$ at $1.9 \%$ shortening.

$\theta=23^{\circ}$. Weated at differential stress of $150 \mathrm{MPa}$ until specimen failed. Shattered)

Shattered, work-softened along multiple fractures to $45 \mathrm{MPa}$ at $2.7 \%$ shortening.

$\theta=34^{\circ}$, work-softened along fault to $15 \mathrm{MPa}$ at $2.5 \%$ shortening.

$\theta=34^{\circ}$, work-softened along fault to $15 \mathrm{MPa}$ at $2.1 \%$ shortening, no welting.

Shattered, work-softened along fault to $25 \mathrm{MPa}$ at $3.2 \%$ shortening partially meiting.

Shattered.

$\theta=27^{\circ}$.

Shattered, $\theta=36^{\circ}$ (best fault).

Shattered, $\theta=34^{\circ}$ (best fault).

Shattered, specimen held at $T=810^{\circ} \mathrm{C} 45$ minutes prior to application of differential stress.

Shattered, work-softened along multiple fractures to $115 \mathrm{MPa}$ at $1.7 \%$ shortening. Shattered, work-softened with stick-sitp to $135 \mathrm{MPa}$ at $2.5 \%$ shortening.

shattered, work-softened along multiple fractures to $60 \mathrm{MPa}$ at $3.4 \%$ shortening. Shat tered.

Shattered, work softened along multiple fractures to $45 \mathrm{MPa}$ at $2.7 \%$ shortening.

Shattered, $\theta=35^{2}$ (best fault)

Shattered, work-softened along multiple fractures to $25 \mathrm{MPa}$ at $1.8 \%$ shortening. Shattered, work-softened along multiple fractures to $25 \mathrm{MPa}$ at $2.0 \%$ shortening. Shattered, work-5oftened along multiple fractures to $20 \mathrm{MPa}$ at $3.5 \%$ shortening. Shattered, work-50ftened along multiple fractures to $15 \mathrm{MPa}$ at $4.0 \%$ shortening. Shattered, work-softened along multiple fractures to $15 \mathrm{MPa}$ at $4.3^{\circ} \mathrm{w}$ shortening. Shattered, work-softened along multiple fractures to $20 \mathrm{MPa}$ at $3.1 \%$ shortening. Ouctile, no fracturing or faulting. total shortening $2.8 \%$ before test stopped. Shattered, work-softened along multiple fractures to $10 \mathrm{MPa}$ at $2.5 \%$ shortening, incipient melting (?)

Shattered, work-softened along multiple fractures to $195 \mathrm{MPa}$ at $3.5 \%$ shortening. Shattered, work-softened along multiple fractures to $215 \mathrm{MPa}$ at $4.1 \%$ shortening. Shattered, work-softened along multiple fractures to $190 \mathrm{MPa}$ at $3.2 \%$ shortening. Ductile, no faults to $3.5 \%$ shortening incipient melting. Ductile, no faults to $3.3 \%$ shortening incipient melting.

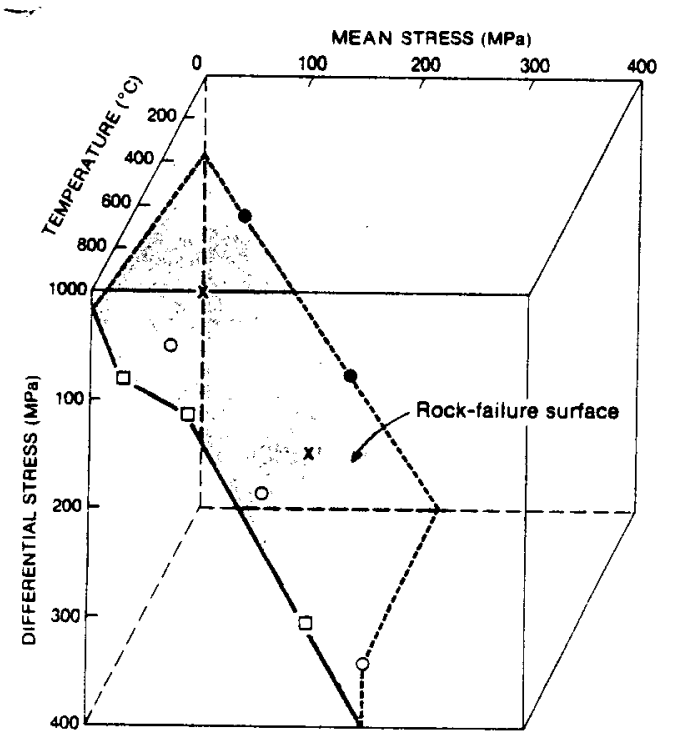

Figure 4. Failure surface for room-dry MHA in three dimensions to be compared with similar data plotted in two dimensions (Figure 5). Differential and mean stress are plotted for $25^{\circ}$ (solid dot), $400^{\circ}$ (cross), $700^{\circ}$ (open circle), and $960-1000^{\circ}$ (open square). 


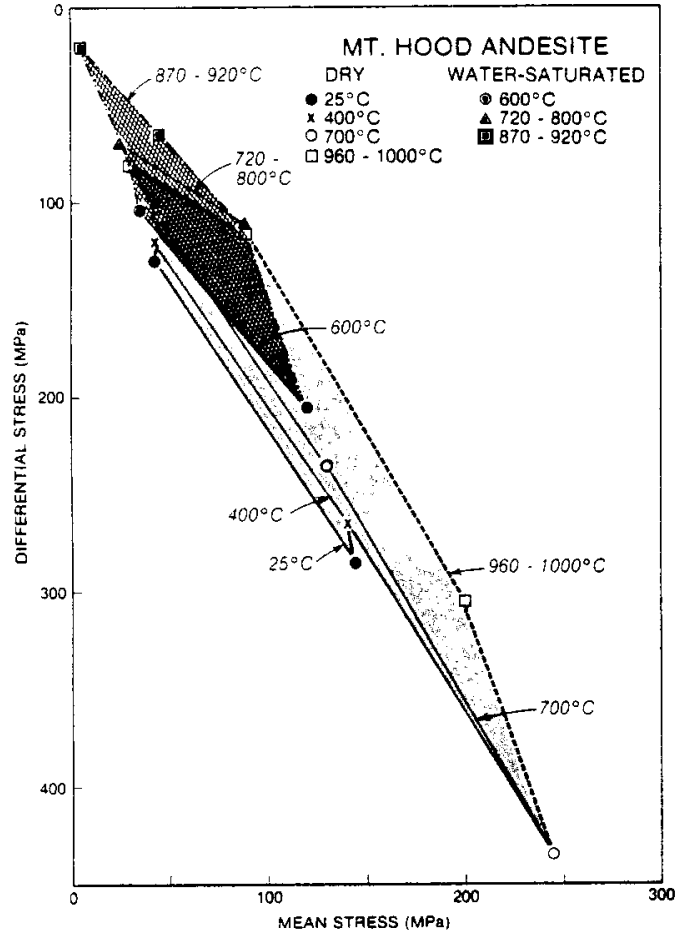

Figure 5. Failure surfaces for room-dry (light gray) and water-saturated (cross-hatched) specimens of Mt. Hood Andesite. Water-weakening has translated the failure surface upwards toward lower mean- and differential-stress levels.

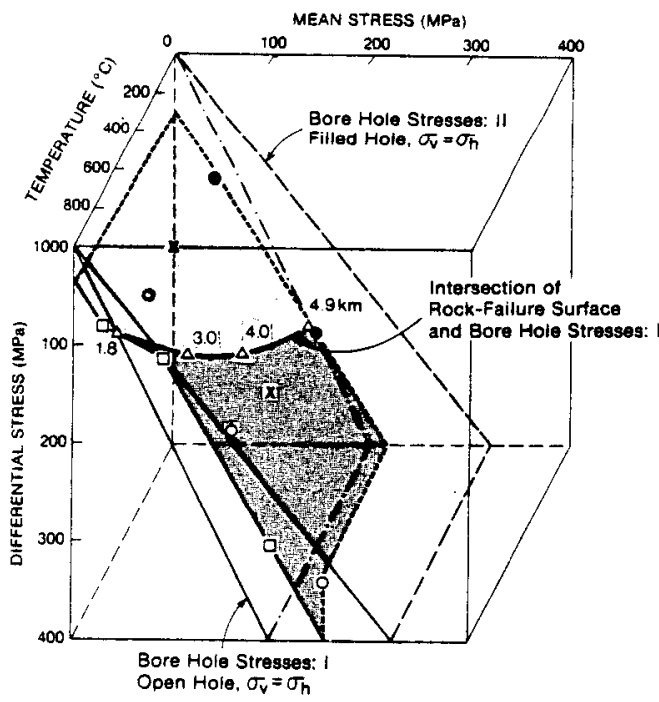

Figure 6. Diagram shows in three dimensions the failure surface for room-dry Mt. Hood Andesite and two sets of borehole stresses (I and II). Failure surface intersects only one loci of borehole stresses (I) at depths of $4.9,4.0,3.0$, and $1.8 \mathrm{~km}$ for temperatures of $25^{\circ}, 400^{\circ}, 700^{\circ}$, and $960-1000^{\circ} \mathrm{C}$, respectively. These depths are determined from the gradient of the borehole stresses, which is fixed for each set of assumptions.

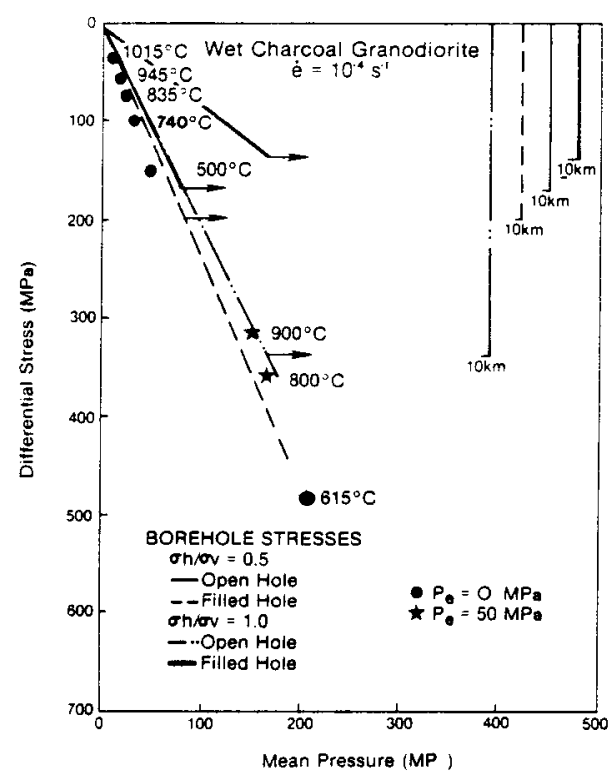

Figure 7. Assessment of borehole stability in water-saturated Charcoal Granodiorite at $\mathrm{Pe}$ of 0 (solid dots) and $50 \mathrm{MPa}$ (solid stars). Temperatures correspond to data located inmediately to left. Four borehole-stress loci and their corresponding depth scales are given. Failure is expected when a line connecting data for a given temperature intersects a borehole stress locus.

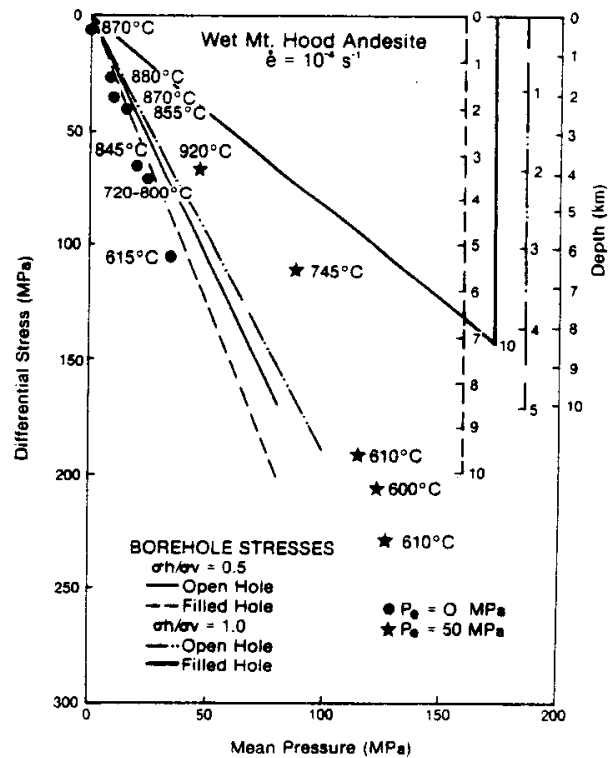

Figure 8. Assessment of borehole stability in water-saturated $M t$. Hood Andesite at $\mathrm{P}_{e}=0$ (solid circles) and $50 \mathrm{MPa}$ (solid stars). Details are same as those in Figure 7. 


\section{DISCLAIMER}

This report was prepared as an account of work sponsored by an agency of the United States Government. Neither the United States Government nor any agency thereof, nor any of their employees, makes any warranty, express or implied, or assumes any legal liability or responsibility for the accuracy, completeness, or usefulness of any information, apparatus, product, or process disclosed, or represents that its use would not infringe privately owned rights. Reference herein to any specific commercial product, process, or service by trade name, trademark, manufacturer, or otherwise does not necessarily constitute or imply its endorsement, recommendation, or favoring by the United States Government or any agency thereof. The views and opinions of authors expressed herein do not necessarily state or reflect those of the United States Government or any agency thereof. 